Gut, 1970, 11, 659-667

\title{
Investigation of gastroesophageal reflux in various positions with a two-lumen $p \mathrm{H}$ electrode
}

\author{
F. G. PATTRICK \\ From the North Cambridgeshire Hospital, Wisbech
}

SUMMARY Normal people without symptoms of reflux do in fact reflux small quantities of acid into the oesophagus when either standing or sitting, but do not reflux acid when they are sleeping lying flat. This 'physiological' incompetence in the upright position is not of great importance in that the oesophagus is able to, and consistently does, deal with small concentrations of refluxed acid material. The oesophageal measurements of $p \mathrm{H}$ have a limited use as a diagnostic measure and may indicate acid reflux in the relaxed person not demonstrated by radiology.

A number of patients have typical symptoms of oesophageal irritation but reflux is not demonstrated at fluoroscopy. Some of these patients show evidence of oesophagitis at oesophagoscopy; a few may have reflux demonstrated by radiology at a later date, but many clinicians feel that they should discard oesophageal irritation as a cause of symptoms if reflux is not demonstrated radiologically, even though the history suggesting reflux is classical. It seemed possible that the discrepancy might arise because the circumstances of the radiological examination did not mimic those in which sufferers experienced these symptoms, and so evidence of the presence of acid in the oesophagus was sought by an indwelling $p \mathrm{H}$ glass electrode. The $p \mathrm{H}$ of the oesophageal contents was estimated continuously throughout a 12- to 24-hour period, through a standard sequence of events and positions of the patient's body. Initial interest was in those who suffered from symptoms of reflux but it was desirable that evidence be sought in a similar way in those without symptoms or radiological evidence of reflux. The results obtained in those without symptoms or radiological evidence of reflux are particularly interesting and have an important bearing on the mechanism of symptom production in reflux.

Received for publication 19 June 1969.

\section{Method}

The Cambridge Instrument Company two-lumen stomach electrode was used (Fig. 1). This consists of a small glass bulb electrode with a fine coaxial wire in one lumen, the other containing saturated potassium chloride solution which is retained by a sintered plug and ends $1.5 \mathrm{~cm}$ proximal to the glass electrode. This proximity of the reference $\mathrm{KCl}$ electrode to the glass electrode eliminates the errors which occur if a finger is placed in the potassium chloride solution as the reference electrode. The whole electrode system can be passed easily through the nose (Fig. 2), giving the patient great freedom of movement and comparative comfort at night. The electrode was connected to a Cambridge Instrument $p \mathrm{H}$ meter, recording on a Record pen-writer with a paper speed of 6 in. per hour. The $p \mathrm{H}$ scale $0-10$ occupied the full width of the paper and a continuous record for 24 hours was possible.

The electrode is passed in the ward about two hours after a light breakfast. With the patient erect, the radiologist positions the electrode in the stomach by reference to his estimate of the position of the hiatus and the dome of the diaphragm made during screening and with the films obtained at a previous barium meal. A 


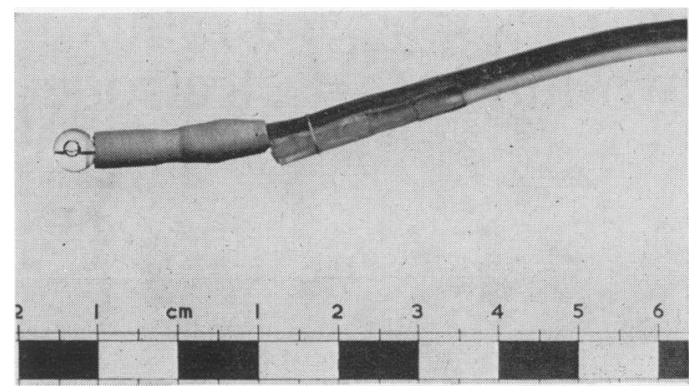

Fig. 1 Detail of the electrode.

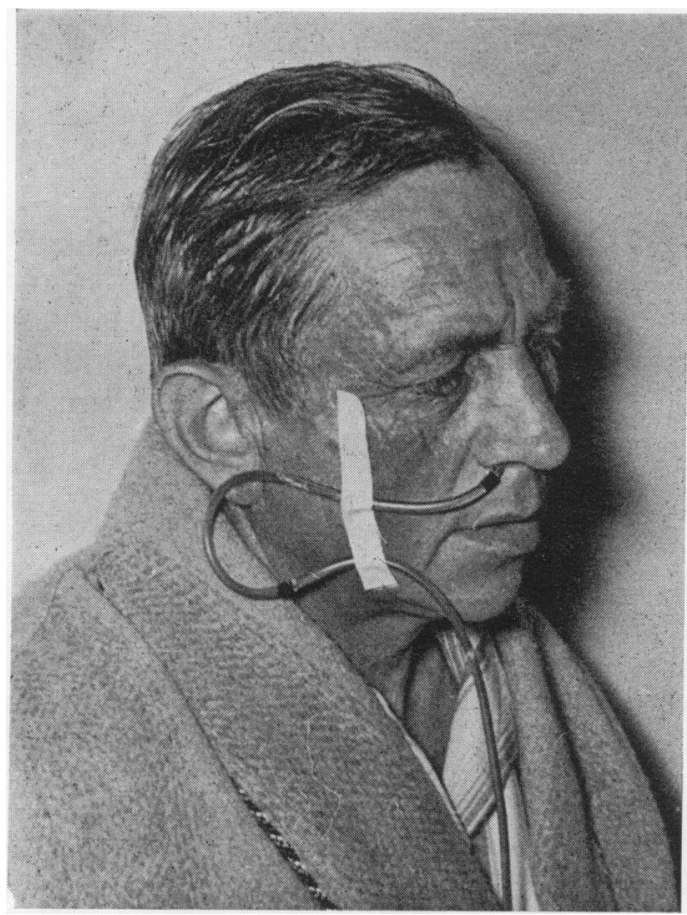

Fig. 2 Electrode in place showing oesophageal and gastric markers.

small Sellotape band is wrapped round the tube, just below the nostril as the stomach marker. The electrode is then withdrawn so that it is about $5 \mathrm{~cm}$ above the estimated level of the hiatus and a second marker placed on the tube. An error in placing would be systematic, and the margin of error was such that the tip would always be above the cardiac sphincter unless a very large hernia was present. The tube is secured firmly to the cheek.

Early in the investigation, acid was found in the oesophagus when its presence there seemed unlikely, so oblique films were taken to see if there was any alteration in the position of the electrode between the standing and sitting positions (Figs. 3 and 4). Films of 10 patients in both the standing and sitting positions showed no appreciable alteration in position.

The patient returns to the ward, the electrode $\Omega$ is connected to the recording apparatus, and the patient remains seated until lunch. This consists $\vec{F}$ of meat and vegetables or a salad, followed by a $\stackrel{\text { ? }}{+}$ sweet, and is eaten standing up. The patient? remains virtually upright for the next two hours if possible, getting some rest by propping himself $\frac{\omega}{\widehat{\sigma}}$ on the edge of the bed. Some of the older patients $\propto$ have found it hard to remain upright for two hours and if they have complained, they have $\vec{\circ}$ been allowed to sit on the edge of the bed.

Tea is taken sitting down at a table and the $\vec{\omega}$ patient remains seated until supper, which is eaten in bed. At 21.30 hours the patient is given $\subsetneq$ $400 \mathrm{mg}$ of sodium amytal and, if desired, a warm $\overrightarrow{-}$ milk drink, and at 22.00 hours he is settled o down for the night on the right side and sup-or ported in this position by bolsters. At 01.30 hours ${ }^{6}$

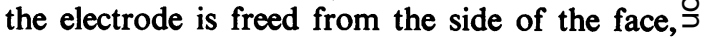
pushed on to the stomach marker and secured in this position. After 30 minutes the patient sits upright, the electrode is withdrawn to the oeso- $\frac{C}{c}$ phageal marker, and he is given a drink of water ${ }^{?}$ to wash the electrode clean. He is then settled $\vec{\theta}$ again for the remainder of the night on the left. side. Sometimes the patient started the night on the left side and was later moved onto the right. The heavy sedation with sodium amytal has reduced the movement of patients on either the right or left side. At 06.30 hours the electrode is $\frac{\mathbb{Q}}{\mathscr{Q}}$ pushed into the stomach and withdrawn com- $\overrightarrow{\vec{O}}$ pletely at $\mathbf{0 7 . 0 0}$ hours.

\section{Patients}

The patients were divided into four groups: Group I consisted of 21 patients with symptoms and radiological evidence of reflux, either with or without hiatus hernia. In group II there were 근 four patients with symptoms of reflux which $>$ was not seen at radiological examination. The control group, group III, contained 22 patients $N_{O}$ without symptoms and without radiological evidence of reflux. Nineteen had duodenal ulceration and so were likely to secrete amounts of acid $\omega$ greater than normal, so that it could be assumed there was acid content in the stomach available for reflux if such reflux did occur. The control $\mathbb{\Phi}_{\infty}^{\Phi}$ group was subdivided. Group IIIa (12 patients) ${ }^{+}$ had the electrode in the oesophagus for a day and $\frac{7}{\circ}$ night with the same procedure as that carried $\stackrel{\mathrm{D}}{\mathrm{P}}$ out in groups I and II. The second half, group $\frac{\mathrm{P}}{\mathrm{D}}$ IIIb, consisted of 10 who were examined standing $\mathrm{Q}$ and sitting and sitting in bed during the day and $\bar{T}$ the electrode was then moved into the stomach,, where it remained all night. The record obtained during the night is not recorded here. In group IV there were two patients with radiological evidence of hiatus hernia with reflux with severe 


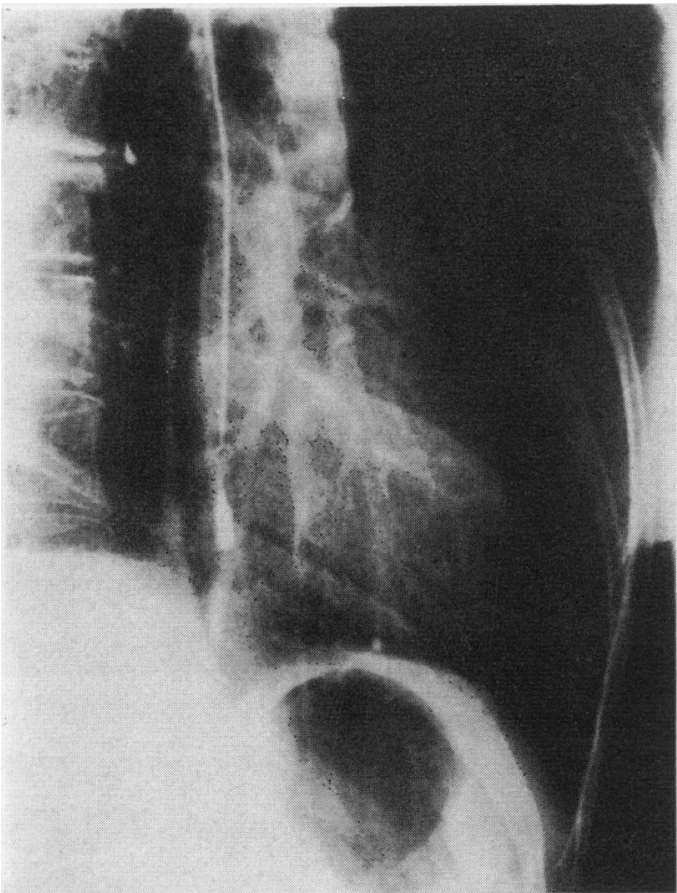

Fig. 3 Oblique radiograph in the standing position. Alteration in the position of the electrode is seen here as in Figure 4.

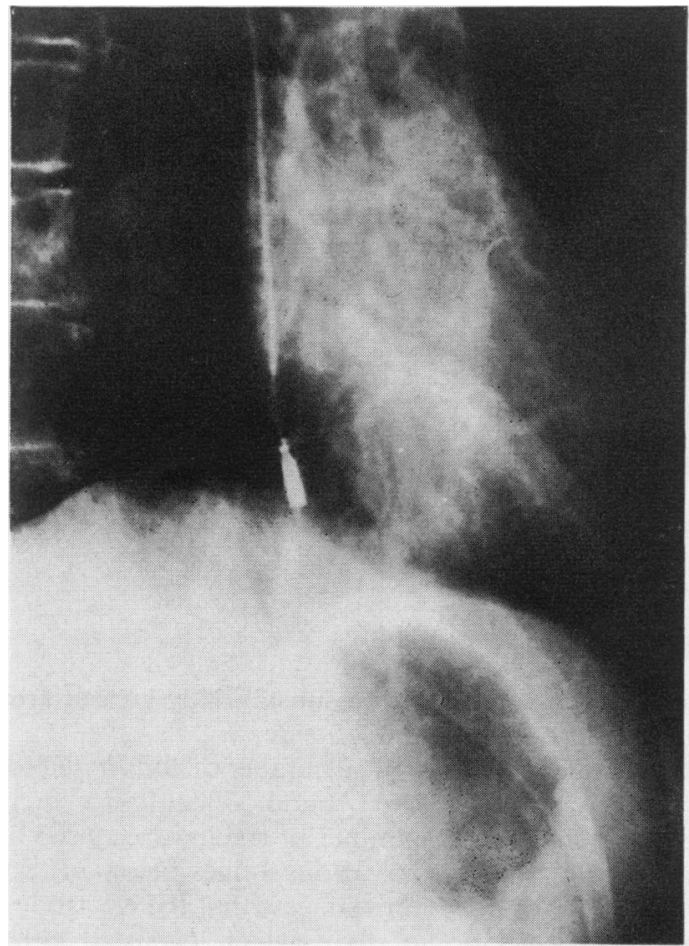

Fig. 4 Oblique radiograph in the sitting position. No alteration in the position of the electrode is seen compared with Figure 3. symptoms, who were examined both before and after repair of the herniae, which was followed by marked clinical improvement.

\section{Results}

The electrode is sensitive and reacts promptly. If the electrode is dipped in the acid gastric juice on the bench there is a sharp deflexion to the $p \mathrm{H}$ of the fluid; as the electrode is then withdrawn to air, there is a gradual return towards $p \mathrm{H} \mathrm{4,}$ which is the open circuit potential of the recording system. Kinking of the tube, sufficient to interrupt the electrical continuity of the $\mathrm{KCl}$ solution, will cause a sharp deflexion towards pH 4. A similar sharp deflexion can be obtained if the electrode is momentarily immersed in acid and then immediately cleaned by a neutral or alkaline solution, such as saliva. In practice it was usually possible to differentiate between a spurious deflexion and one due to a change in $p \mathrm{H}$. When saliva is repeatedly swallowed as rapidly as possible after swallowing a small amount of $\mathrm{HCl}$, there is some lag before neutralization is recorded, and it is likely that this lag would also occur after acid is refluxed into the oesophagus.

It is not possible to measure the amount of acid reaching the oesophagus by the present method but the frequency and duration of the fall in $p \mathrm{H}$ can be used to quantitate the reflux. The extent of the fall in $p \mathrm{H}$ will reflect to some extent the quantity of acid refluxed, and the duration of the fall will reflect the duration of exposure of the mucosa to the refluxed material. The tracings have been analysed, first, by measuring with a planimeter the area in $\mathrm{cm}^{2}$ between the trace and a baseline of $p \mathrm{H} 5$ and, secondly, by counting the number of falls of $p \mathrm{H}$ to various values in four steps (ie, $p H$ 1-2, 2-3, 3-4, and 4-5). A baseline of $p \mathrm{H} 5$ gives a more accurate picture of the degree of reflux than would be obtained by using a baseline of $p H$ 7, at which level the minor changes due to instability of the electrode and recording apparatus could give a misleading impression. A number of illustrative tracings are shown in Figs. 5, 6, 7, and 8, and the values obtained for the three groups of patients and the two subgroups of controls in Tables I, II, III, IV, and V. If the trace has been steady at a $p H$ above 5 a zero is entered for the area measurement; if the trace has recorded a steady $p \mathrm{H}$ above 5 , except for an occasional sharp deflexion with rapid return, a figure of 0.5 or less is entered for the area.

A fall in oesophageal $p \mathrm{H}$ indicates that acid has refluxed from the stomach, and it is clear from the records obtained in the asymptomatic patients with quiescent duodenal ulcers and no radiological evidence of reflux that short bursts of gastrooesophageal reflux occurred at frequent 


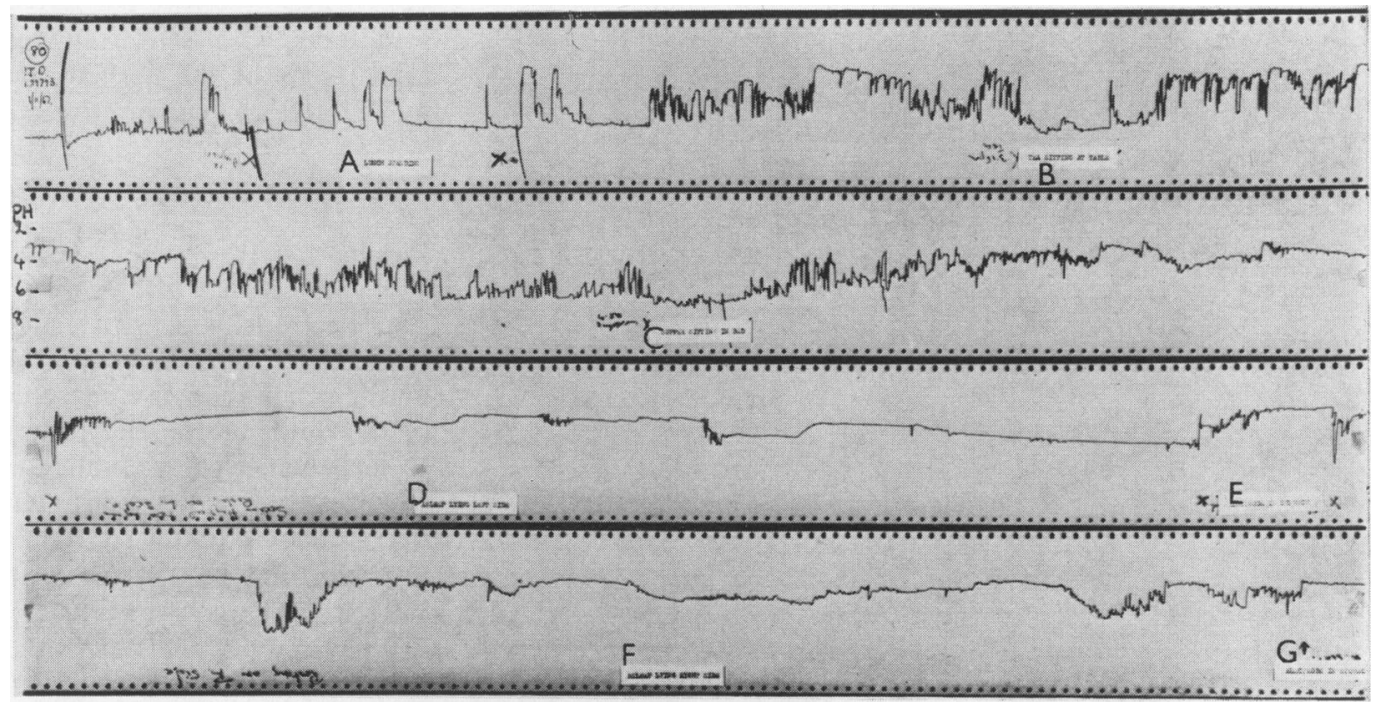

Fig. 5 A complete tracing from a patient with reflux, showing in particular the sustained level of acid in the oesophagus at night.

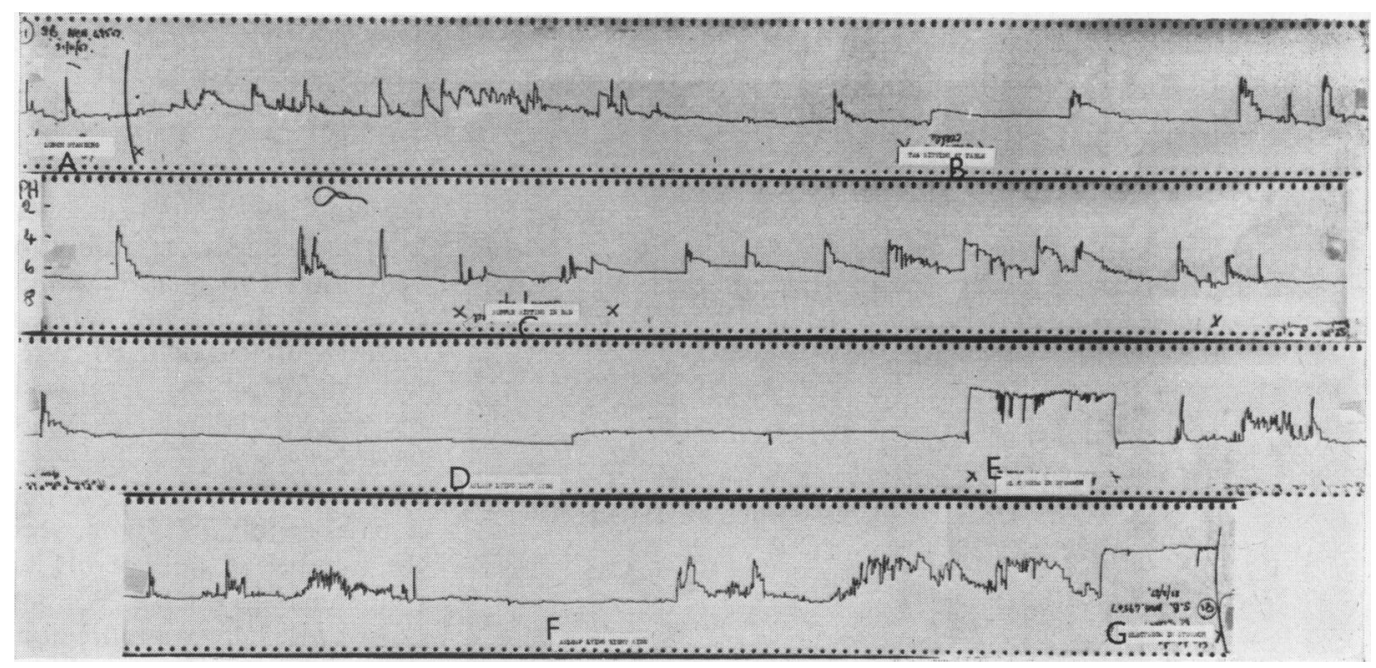

Fig. 6 A complete tracing from a patient with reflux, showing in particular the falls in $\mathrm{pH}$ when asleep on the right side.

Key to Figs. 5 and 6: $A$, lunch standing; $B$, tea sitting at table; $C$, supper sitting in bed; $D$, asleep lying on left side; E, electrode in stomach; $F$, asleep lying on right side; $G$, electrode in stomach.

intervals after meals in both the standing and sitting positions, but that when these patients were asleep, on either side, reflux was negligible.

By contrast, in those patients with symptoms and radiological evidence of reflux about the same area was recorded under the tracing as in those without symptoms when standing or sitting. For three-quarters of those with symptoms a substantially greater area was recorded under the curve when sleeping on the right side than for those without symptoms, and one patient had a substantially greater area when sleeping on? the left side.

The number of falls in $p \mathrm{H}$ to the various values was found difficult to quantitate because $a \frac{\rho}{\odot}$ number of tracings recorded a steady level of $p \mathrm{H} \stackrel{\odot}{\circ}$ at various values below $p \mathrm{H} 5$. These steady tracings suggest that the electrode was lying in a poolo of fluid which persisted either because of sus-? tained incompetence of the oesophagogastric closing mechanism, or because of failure of a? peristaltic wave to wipe the oesophagus clean. 


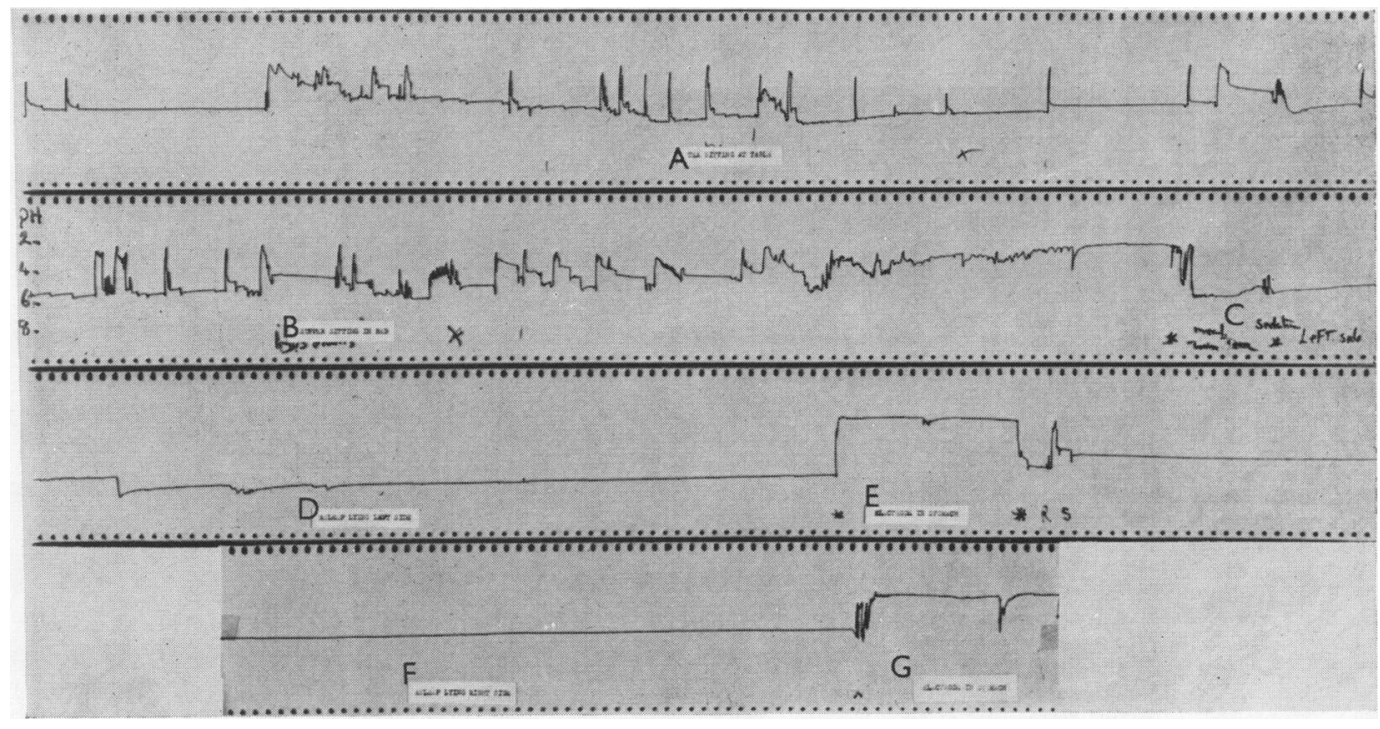

Fig. 7 A complete tracing from a control patient with a duodenal ulcer (key as for Figures 5 and 6).

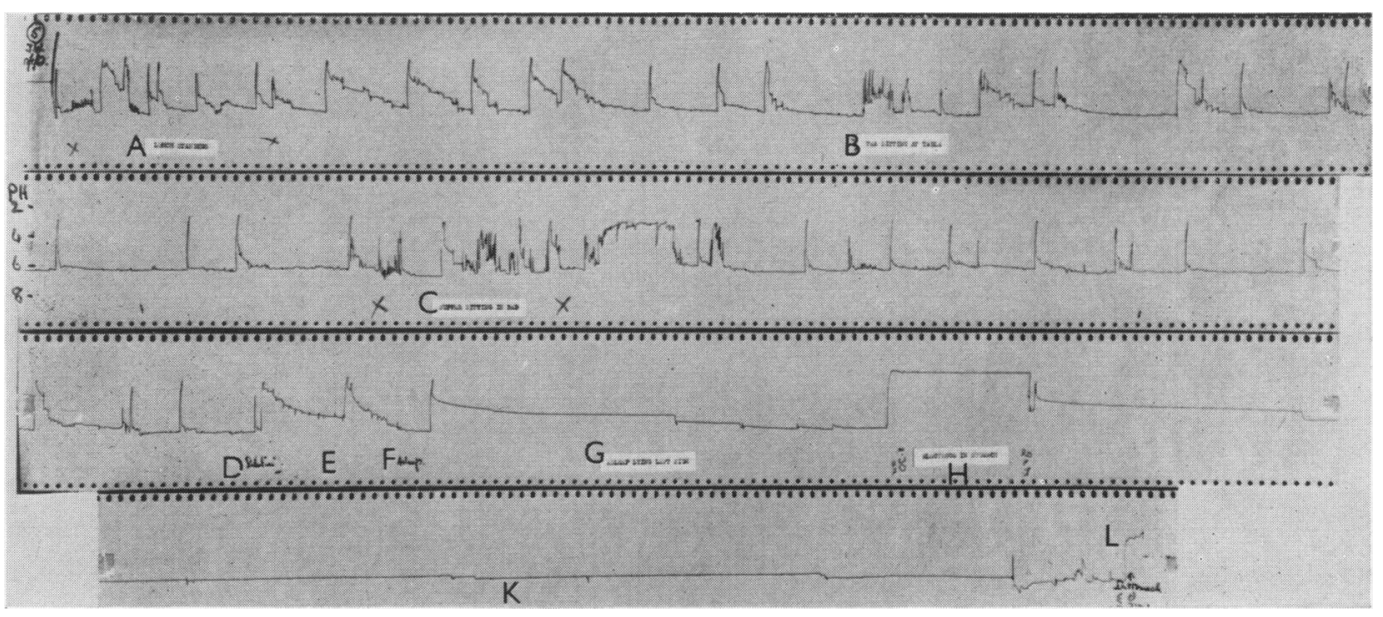

Fig. 8 A complete tracing from a control patient suffering from an anxiety state. It will be seen that the pattern of the tracing in the standing, sitting, and sitting in bed positions in Figs. 7 and 8 is not greatly different from that in Figure 6. However, there is no suggestion of acid in the oesophagus at night when asleep on either the right or the left side.

The mean number of peaks recorded at each $p \mathrm{H}$ range in the controls was similar to the mean number recorded in those with symptoms of reflux, except during the night, when more peaks were recorded in those with symptoms of reflux.

\section{Discussion}

The results indicate that reflux into the oeso$2^{*}$
$A$, lunch standing; $B$, tea sitting at table; $C$, supper sitting in bed. $D$, Sedation. E, Patient restless.

$F$, patient becoming drowsy; $G$, asleep lying left side; $H$, electrode in stomach; $K$, asleep lying right side; $L$, electrode in stomach.

phagus of gastric contents of low $p \mathrm{H}$ occurs almost as commonly in people without symptoms as in those with symptoms during the day when the patient is standing or sitting. Nor is the difference particularly prominent when the patient lies on the left side in bed. But those who suffer symptoms of reflux appear to reflux much more frequently when lying on the right side than do those who do not suffer symptoms. The similarity of the tracings obtained in both groups during the day might suggest that technical factors were 


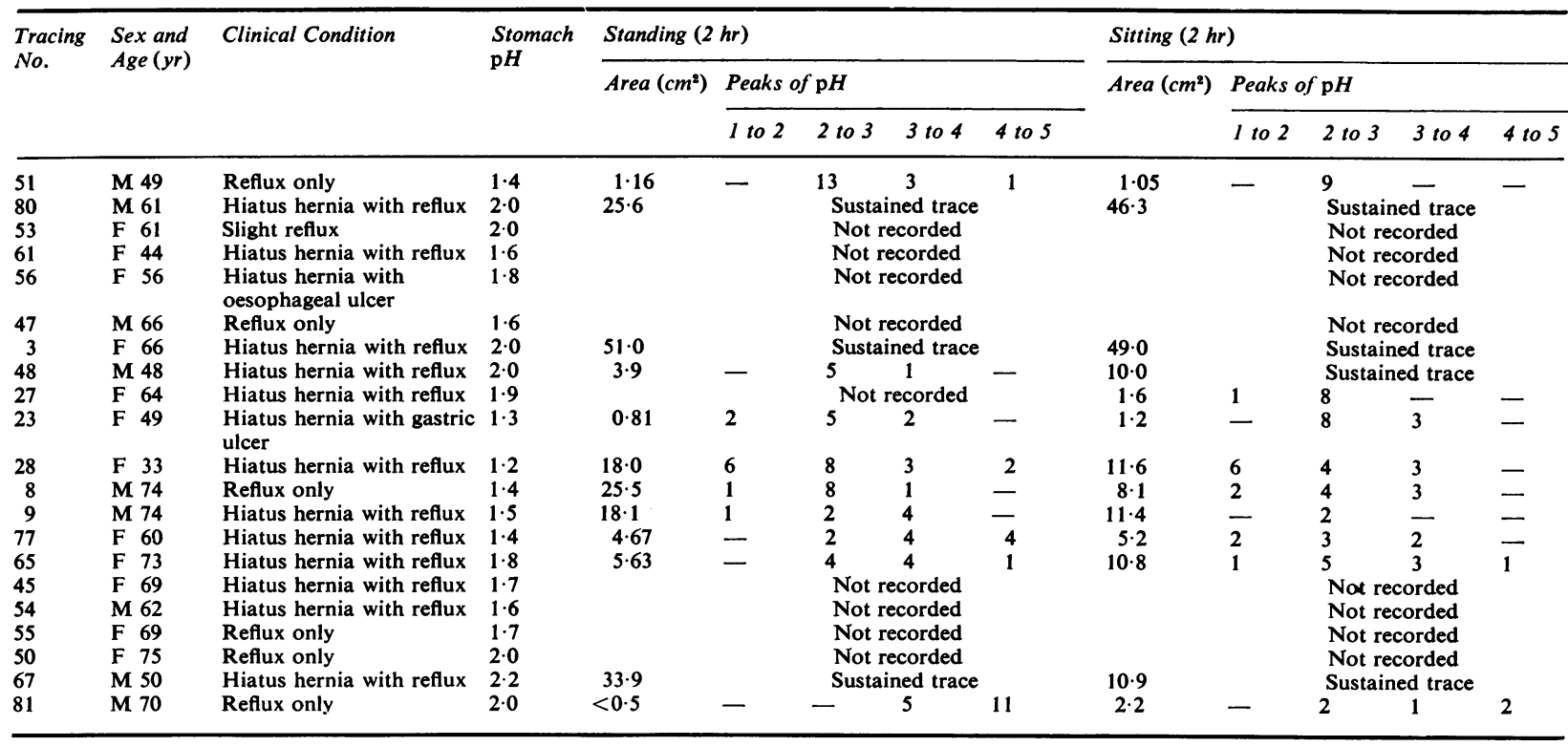

Table I Values obtained from the tracings for patients in group I

\begin{tabular}{|c|c|c|c|c|c|c|c|c|c|c|c|c|c|}
\hline \multirow{3}{*}{$\begin{array}{l}\text { Tracing } \\
\text { No. }\end{array}$} & \multirow{3}{*}{$\begin{array}{l}\text { Sex and } \\
\text { Age }(y r)\end{array}$} & \multirow[t]{3}{*}{ Clinical Condition } & \multirow{3}{*}{$\begin{array}{l}\text { Stomach } \\
\mathrm{pH}\end{array}$} & \multicolumn{5}{|c|}{ Standing (2 hr) } & \multicolumn{5}{|c|}{ Sitting $(2 \mathrm{hr})$} \\
\hline & & & & \multirow[t]{2}{*}{$\operatorname{Area}\left(\mathrm{cm}^{2}\right)$} & \multicolumn{4}{|c|}{ Peaks of $\mathrm{p} H$} & \multirow[t]{2}{*}{ Area $\left(\mathrm{cm}^{2}\right)$} & \multicolumn{4}{|c|}{ Peaks of $\mathrm{pH}$} \\
\hline & & & & & 1 to 2 & 2 to 3 & 3 to 4 & 4 to 5 & & 1 to 2 & 2 to 3 & 3 to 4 & 4 to 5 \\
\hline $\begin{array}{l}16 \\
33 \\
42\end{array}$ & $\begin{array}{l}\text { M } 62 \\
\text { F } 57 \\
\text { M } 42\end{array}$ & $\begin{array}{l}\text { Symptoms of reflux } \\
\text { Symptoms of reflux } \\
\text { Oesophagitis with bleeding }\end{array}$ & $\begin{array}{l}2 \cdot 2 \\
2 \cdot 0 \\
2 \cdot 0\end{array}$ & \multicolumn{5}{|c|}{$\begin{array}{l}\text { Not recorded } \\
\text { Not recorded } \\
\text { Not recorded }\end{array}$} & & \multicolumn{4}{|c|}{$\begin{array}{l}\text { Not recorded } \\
\text { Not recorded } \\
\text { Not recorded }\end{array}$} \\
\hline 12 & F 65 & $\begin{array}{l}\text { Symptoms of reflux and } \\
\text { oesophageal spasm }\end{array}$ & $1 \cdot 2$ & $11 \cdot 3$ & 1 & 2 & 5 & 一 & $<0.5$ & - & 2 & 2 & - \\
\hline
\end{tabular}

Table II Values obtained from the tracing for patients in group II

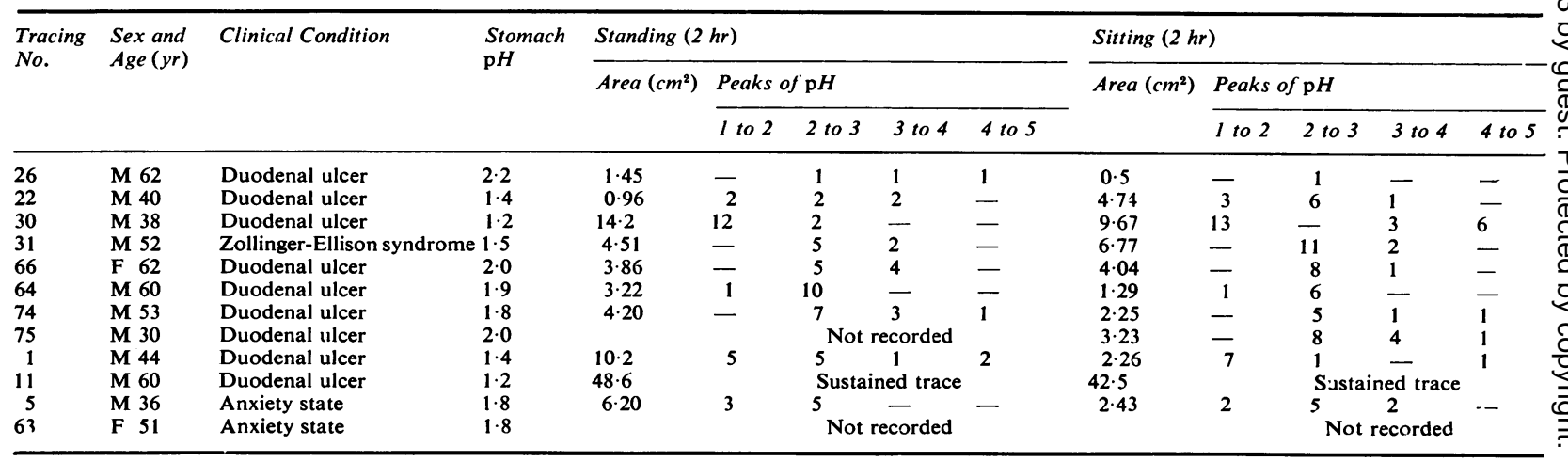




\begin{tabular}{|c|c|c|c|c|c|c|c|c|c|c|c|c|c|c|}
\hline \multicolumn{5}{|c|}{ Sitting in Bed $(2 \mathrm{hr})$} & \multicolumn{5}{|c|}{ Asleep on Right Side (4 hr) } & \multicolumn{5}{|c|}{ Asleep on Left Side $(4 \mathrm{hr})$} \\
\hline \multirow[t]{2}{*}{ Area $\left(\mathrm{cm}^{2}\right)$} & \multicolumn{4}{|c|}{ Peaks of $\mathrm{pH}$} & \multirow[t]{2}{*}{ Area $\left(\mathrm{cm}^{2}\right)$} & \multicolumn{4}{|c|}{ Peaks of $\mathrm{p} H$} & \multirow[t]{2}{*}{ Area $\left(\mathrm{cm}^{2}\right)$} & \multicolumn{4}{|c|}{ Peaks of $\mathrm{p} H$} \\
\hline & 1 to 2 & 2 to 3 & 3 to 4 & 4 to 5 & & 1 to 2 & 2 to 3 & 3 to 4 & 4 to 5 & & 1 to 2 & 2 to 3 & 3 to 4 & 4 to 5 \\
\hline 1.2 & - & 7 & 2 & 4 & 0.7 & - & 1. & - & - & 0.0 & & Sustai & led trace & \\
\hline 53.0 & & Sustai & ned trace & & $189 \cdot 0$ & & Sustai & led trace & & 166.0 & & Sustai & led trace & \\
\hline 5.05 & & Sustai & ned trace & & $11 \cdot 0$ & & Sustai & hed trace & & 0.0 & & Sustai & led trace & 2 \\
\hline $8 \cdot 25$ & & Sustai & ned trace & & $35 \cdot 3$ & & Sustai & led trace & & 0.0 & - & 1 & - & - \\
\hline $6 \cdot 0$ & & Sustai & ned trace & & $13 \cdot 2$ & & Sustair & led trace & & $6 \cdot 1$ & & Sustai & led trace & \\
\hline $7 \cdot 3$ & & Sustai & ned trace & & $16 \cdot 5$ & & Sustai & ned trace & & $19 \cdot 2$ & & Sustai & led trace & \\
\hline $49 \cdot 3$ & & Sustai & ned trace & & $96 \cdot 1$ & & Sustai & ned trace & & $93 \cdot 5$ & & Sustai & led trace & \\
\hline $10 \cdot 0$ & & Susta & ned trace & & $42 \cdot 0$ & & Sustai & ned trace & & $6 \cdot 2$ & - & 3 & - & - \\
\hline $8 \cdot 1$ & - & 7 & 4 & - & $20 \cdot 1$ & & Sustai & ned trace & & 0.0 & & Sustai & led trace & \\
\hline 0.9 & - & 4 & 3 & - & 0.0 & & Sustai & ed trace & & $0 \cdot 0$ & & Sustai & ed trace & \\
\hline $21 \cdot 2$ & 3 & 8 & 8 & 2 & 0.0 & & Sustai & ned trace & & 0.0 & & Sustai & led trace & \\
\hline $15 \cdot 4$ & 5 & 5 & 3 & 2 & $47 \cdot 0$ & & Sustai & ned trace & & $100 \cdot 0$ & 1 & 3 & 5 & - \\
\hline $20 \cdot 9$ & 2 & 1 & 2 & - & $33 \cdot 8$ & & Sustai & ned trace & & $0 \cdot 0$ & & Sustai & led trace & \\
\hline $8 \cdot 1$ & - & 3 & - & - & 0.0 & & Sustai & ned trace & & 0.0 & & Sustai & led trace & \\
\hline $26 \cdot 4$ & 2 & 4 & - & - & 0.0 & & Sustai & ned trace & & 0.0 & & Sustai & led trace & \\
\hline $3 \cdot 22$ & - & 4 & 4 & 11 & 5.63 & 1 & 8 & 1 & - & 0.0 & - & 2 & 1 & - \\
\hline $14 \cdot 1$ & & Susta & ned trace & & 108.0 & & Sustai & ned trace & & $19 \cdot 3$ & & Sustai & led trace & \\
\hline $3 \cdot 4$ & - & 6 & 2 & 3 & $13 \cdot 0$ & & Sustai & ned trace & & 1.69 & - & - & 5 & - \\
\hline 0.64 & - & 1 & 4 & - & $8 \cdot 25$ & - & 5 & 2 & - & 0.0 & & Sustai & led trace & \\
\hline $13 \cdot 2$ & & Susta & ned trace & & 0.0 & & Sustai & ned trace & & 0.0 & & Sustai & hed trace & \\
\hline $4 \cdot 6$ & - & - & 8 & - & $11 \cdot 2$ & - & 4 & 4 & 5 & 0.0 & & Sustai & hed trace & \\
\hline
\end{tabular}

Table I Values obtained from the tracings for patients in group I-continued

\begin{tabular}{|c|c|c|c|c|c|c|c|c|c|c|c|c|c|c|}
\hline \multicolumn{5}{|c|}{ Sitting in Bed $(2 \mathrm{hr})$} & \multicolumn{5}{|c|}{ Asleep on Right Side (4 hr) } & \multicolumn{5}{|c|}{ Asleep on Left Side $(4 \mathrm{hr})$} \\
\hline \multirow[t]{2}{*}{ Area $\left(\mathrm{cm}^{2}\right)$} & \multicolumn{4}{|c|}{ Peaks of $\mathrm{pH}$} & \multirow[t]{2}{*}{$\overline{\operatorname{Area}\left(\mathrm{cm}^{2}\right)}$} & \multicolumn{4}{|c|}{ Peaks of $\mathrm{pH}$} & \multirow[t]{2}{*}{ Area $\left(\mathrm{cm}^{2}\right)$} & \multicolumn{4}{|c|}{ Peaks of $\mathrm{pH}$} \\
\hline & 1 to 2 & 2 to 3 & 3 to 4 & 4 to 5 & & 1 to 2 & 2 to 3 & 3 to 4 & 4 to 5 & & 1 to 2 & 2 to 3 & 3 to 4 & 4 to 5 \\
\hline $\begin{array}{c}30 \cdot 4 \\
4 \cdot 35 \\
22 \cdot 7 \\
6 \cdot 3\end{array}$ & - & ${ }_{6}^{\text {Susta }}$ & $\begin{array}{l}\text { ned trace } \\
3 \\
\text { ned trace } \\
2\end{array}$ & $\begin{array}{r}4 \\
-\end{array}$ & $\begin{array}{r}<0.5 \\
79.0 \\
63.5 \\
9.65\end{array}$ & - & $\begin{array}{l}{ }_{2}^{\text {Susta }} \\
\text { Susta }\end{array}$ & $\begin{array}{l}-\bar{c} \\
\text { ned trace } \\
\text { ned trace } \\
-\end{array}$ & $\begin{array}{l}- \\
-\end{array}$ & $\begin{array}{r}<0.5 \\
<0.5 \\
21.3 \\
0.0\end{array}$ & $\bar{z}$ & $\frac{2}{2}$ & $\frac{1}{3}$ & $\begin{array}{l}- \\
4\end{array}$ \\
\hline
\end{tabular}

Table II Values obtained from the tracing for patients in group II-continued

\begin{tabular}{|c|c|c|c|c|c|c|c|c|c|c|c|c|c|c|}
\hline \multicolumn{5}{|c|}{ Sitting in Bed $(2 \mathrm{hr})$} & \multicolumn{5}{|c|}{ Asleep on Right Side (4 hr) } & \multicolumn{5}{|c|}{ Asleep on Left Side (4 hr) } \\
\hline \multirow[t]{2}{*}{ Area $\left(\mathrm{cm}^{2}\right)$} & \multicolumn{4}{|c|}{ Peaks of $\mathrm{pH}$} & \multirow[t]{2}{*}{ Area $\left(\mathrm{cm}^{2}\right)$} & \multicolumn{4}{|c|}{ Peaks of $\mathrm{pH}$} & \multirow[t]{2}{*}{ Area $\left(\mathrm{cm}^{2}\right)$} & \multicolumn{4}{|c|}{ Peaks of $\mathrm{pH}$} \\
\hline & 1 to 2 & 2 to 3 & 3 to 4 & 4 to 5 & & 1 to 2 & 2 to 3 & 3 to 4 & 4 to 5 & & 1 to 2 & 2 to 3 & 3 to 4 & 4 to 5 \\
\hline 0.5 & - & 4 & 2 & 1 & 0.0 & & \multicolumn{3}{|c|}{ Sustained trace } & 0.0 & & \multicolumn{3}{|c|}{ Sustained trace } \\
\hline $8 \cdot 89$ & 2 & 8 & 1 & - & 16.9 & 3 & 4 & - & 1 & $3 \cdot 85$ & 3 & - & - & - \\
\hline 6.29 & 9 & 1 & 3 & 1 & 0.0 & & & 0.0 & & \multirow{2}{*}{\multicolumn{3}{|c|}{$\begin{array}{l}\text { Sustained trace } \\
\text { Sustained trace }\end{array}$}} \\
\hline $2 \cdot 1$ & - & 2 & 3 & 1 & 0.0 & & & & & 0.0 & & & & \\
\hline $16 \cdot 8$ & - & 5 & 3 & 1 & 0.0 & & \multicolumn{2}{|c|}{ Sustained trace } & & 0.0 & & \multicolumn{3}{|c|}{ Sustained trace } \\
\hline 6.46 & 1 & 11 & 1 & - & & & \multicolumn{2}{|c|}{ Not recorded } & & 0.0 & & \multicolumn{3}{|c|}{ Sustained trace } \\
\hline 2.90 & - & 4 & 3 & - & $0 \cdot 0$ & & \multirow{2}{*}{\multicolumn{2}{|c|}{ Sustained trace }} & & 0.0 & & \multicolumn{2}{|c|}{ Sustained trace } & \\
\hline $3 \cdot 70$ & - & 7 & 7 & 1 & 0.0 & & & & & $0 \cdot 0$ & & \multirow{2}{*}{\multicolumn{2}{|c|}{$\begin{array}{l}\text { Sustained trace } \\
\text { Sustained trace }\end{array}$}} & \\
\hline $10 \cdot 19$ & 9 & 3 & 1 & - & 0.0 & & \multicolumn{2}{|c|}{ Sustained trace } & & 0.0 & & & & \\
\hline $44 \cdot 5$ & & Susta & ned trace & & 0.0 & & \multicolumn{2}{|c|}{ Sustained trace } & & 0.0 & & \multicolumn{2}{|c|}{ Sustainer trace } & \\
\hline 5.81 & - & 7 & 2 & 1 & 1.99 & - & 3 & - & - & 0.0 & & \multirow{2}{*}{\multicolumn{2}{|c|}{$\begin{array}{l}\text { Sustained trace } \\
\text { Sustained trace }\end{array}$}} & \\
\hline 0.96 & - & 2 & 3 & - & 0.0 & & \multicolumn{2}{|c|}{ Sustained trace } & & 0.0 & & & & \\
\hline
\end{tabular}




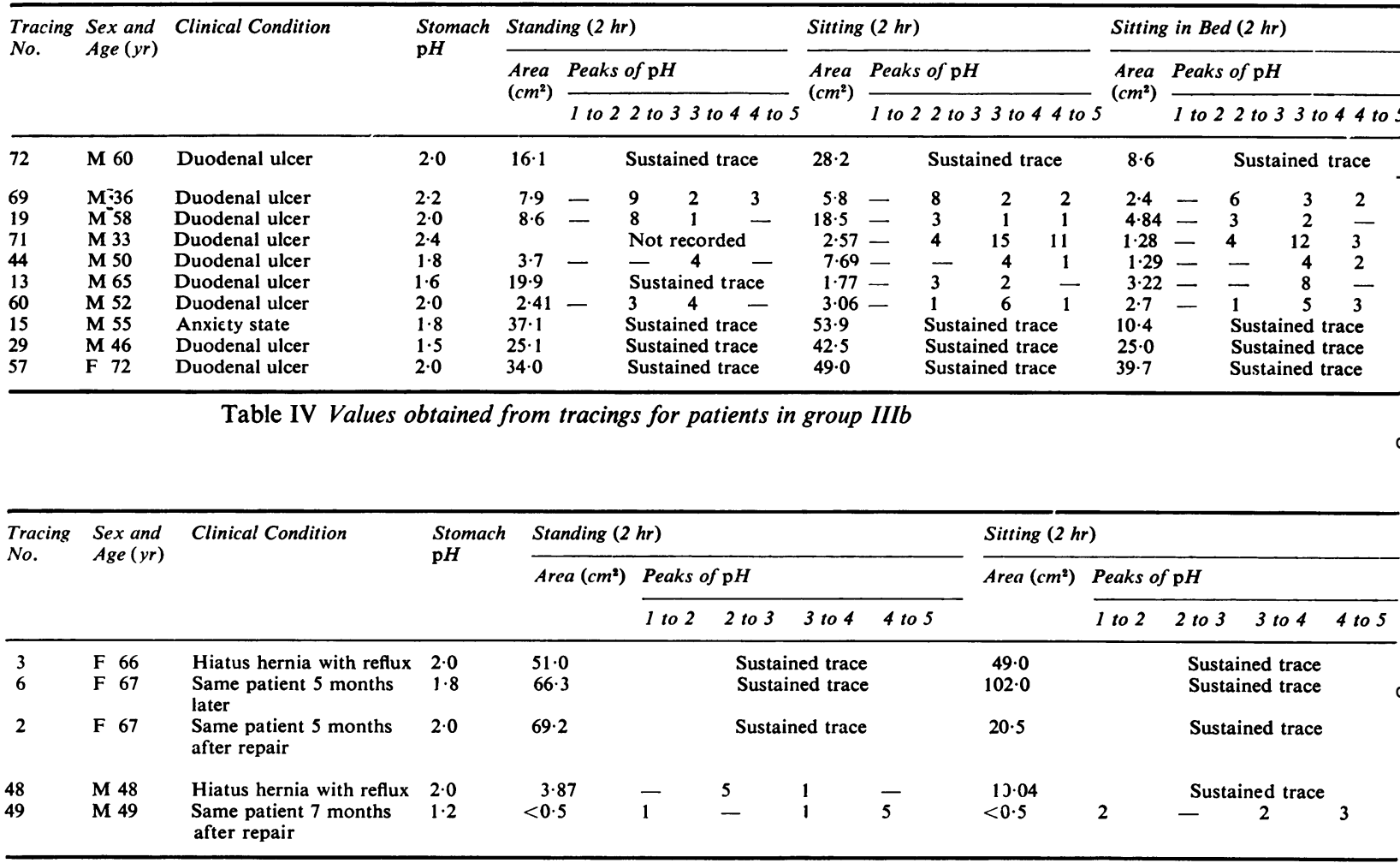

Table V Values obtained from tracings for patients in group IV 
blurring the result or that artefacts were entirely responsible for the tracings, but the dissimilarity of the night tracings and the experiments in vitro suggest that the method and the results obtained are valid.

Whether or not a person complains of reflux seems therefore to depend not so much on the occurrence of reflux as on the sensitivity of the oesophagus when reflux occurs. What determines the sensitivity of the oesophagus may be the amount of reflux which occurs during the night and especially that which occurs when the subject is sleeping on the right side.

I wish to thank Dr D. A. W. Edwards of the MRC Department of Clinical Research, University College Hospital, London, for his continued encouragement and advice throughout this work, and the East Anglian Regional Hospital Board for a grant from its clinical research fund.

\begin{tabular}{|c|c|c|c|c|c|c|c|c|c|c|c|c|c|c|}
\hline \multicolumn{5}{|c|}{ Sitting in Bed $(2 \mathrm{hr})$} & \multicolumn{5}{|c|}{ Asleep on Right Side (2 hr) } & \multicolumn{5}{|c|}{ Asleep on Left Side $(2 \mathrm{hr})$} \\
\hline \multirow[t]{2}{*}{ Area $\left(\mathrm{cm}^{2}\right)$} & \multicolumn{4}{|c|}{ Peaks of $\mathrm{p} H$} & \multirow[t]{2}{*}{ Area $\left(\mathrm{cm}^{2}\right)$} & \multicolumn{4}{|c|}{ Peaks of $\mathrm{pH}$} & \multirow[t]{2}{*}{ Area $\left(\mathrm{cm}^{2}\right)$} & \multicolumn{4}{|c|}{ Peaks of $\mathrm{pH}$} \\
\hline & 1 to 2 & 2 to 3 & 3 to 4 & 4 to 5 & & 1 to 2 & 2 to 3 & 3 to 4 & 4 to 5 & & 1 to 2 & 2 to 3 & 3 to 4 & 4 to 5 \\
\hline $\begin{array}{r}49 \cdot 3 \\
124 \cdot 5\end{array}$ & & \multicolumn{3}{|c|}{$\begin{array}{l}\text { Sustained trace } \\
\text { Sustained trace }\end{array}$} & $\begin{array}{r}96 \cdot 1 \\
142 \cdot 0\end{array}$ & & \multicolumn{3}{|c|}{$\begin{array}{l}\text { Sustained trace } \\
\text { Sustained trace }\end{array}$} & $\begin{array}{l}93 \cdot 5 \\
88 \cdot 1\end{array}$ & & \multicolumn{3}{|c|}{$\begin{array}{l}\text { Sustained trace } \\
\text { Sustained trace }\end{array}$} \\
\hline $86 \cdot 0$ & & \multicolumn{3}{|c|}{ Sustained trace } & $0 \cdot 0$ & & \multicolumn{3}{|c|}{ Sustained trace } & $74 \cdot 0$ & & \multicolumn{3}{|c|}{ Sustained trace } \\
\hline $\begin{array}{c}10 \cdot 0 \\
3.69\end{array}$ & 2 & \multicolumn{3}{|c|}{ Sustained trace } & $\begin{array}{c}42 \cdot 0 \\
4 \cdot 61\end{array}$ & - & \multicolumn{3}{|c|}{ Sustained trace } & $\begin{array}{l}6.22 \\
0.0\end{array}$ & - & \multicolumn{2}{|c|}{ Sustained trace } & - \\
\hline
\end{tabular}

Table V Values obtained from tracings for patients in group IV-continued 